\title{
Heterogeneous Effects of Credit Constraints on SMEs' Employment: Evidence from the European Sovereign Debt Crisis
}

\author{
David Cornille \\ National Bank of Belgium \\ Boulevard du Berlaimont, 3 \\ B-1000 Brussels, Belgium \\ David.Cornille@nbb.be \\ François Rycx (Corresponding author) \\ Université libre de Bruxelles, SBS-EM (CEB, DULBEA), IRES, humanOrg, GLO \& IZA \\ 50 avenue F. Roosevelt, CP114/03 \\ B-1050 Brussels, Belgium \\ frycx@ulb.ac.be \\ Ilan Tojerow \\ Université libre de Bruxelles, SBS-EM (CEB, DULBEA) \& IZA \\ 50 avenue F. Roosevelt, CP114/03 \\ B-1050 Brussels, Belgium \\ itojerow@ulb.ac.be
}

\begin{abstract}
This paper takes advantage of access to detailed matched bank-firm data to investigate whether and how employment decisions of SMEs have been affected by credit constraints during the European sovereign debt crisis. Variability in banks' financial health following the 2008 crisis is used as an exogenous determinant of firms' access to credit. Findings, relative to the Belgian economy, clearly highlight that credit matters. They show that SMEs borrowing money from pre-crisis financially less healthy banks were significantly more likely to be affected by a credit constraint and, in turn, to adjust their labour input downwards than pre-crisis clients of more healthy banks. These results are robust across types of loan applications that were denied credit, i.e. applications to finance working capital, debt or new investments. Yet, estimates also show that credit constraints have been essentially detrimental for employment among SMEs experiencing a negative demand shock or facing strong product market competition. In terms of human resources management, credit constraints are not only found to foster employment adjustment at the extensive margin but also to increase the use of temporary layoff allowances for economic reasons. This outcome supports the hypothesis that short-time compensation programmes contribute to save jobs during recessions.
\end{abstract}

Keywords: banks' financial health, credit constraints, employment, short-time compensation programmes, European sovereign debt crisis.

JEL Codes: C35, C36, D22, G21, J21, J23.

Number of words : 9,776

Acknowledgements: We are grateful to the National Bank of Belgium (NBB) for financial support and for providing access to the data. We also would like to thank the Editor Iftekhar Hasan, an anonymous referee and participants at the NBB Workshop (September 2017) and 
the European Central Bank Wage Dynamics' Meeting (December 2015) and Conference (December 2017), and especially Samuel Bentolila, Reamonn Lydon, Ana Lamo, Sébastien Roux, Clémence Berson, Philippe Delhez, Olivier De Jonghe, Christophe Piette and Catherine Fuss, for helpful suggestions and comments which significantly improved the content of the paper. A special thank you also to Patrick Bissot. The views expressed in this paper do not necessarily reflect those of the NBB.

Funding: This work was supported by the National Bank of Belgium.

Declaration of interest: None. 


\section{Introduction}

Small- and medium-sized enterprises (SMEs) constitute the core of the European economy. In 2013 , they totalled more than $99 \%$ of all active European firms and employed roughly $70 \%$ of the overall labour force (Muller et al., 2014). Therefore, questions related to the performance of SMEs have attracted a large share of attention in debates concerning the post-2008 crisis and the consequent economic recovery. The focus has notably been on the challenges that SMEs face in terms of credit constraints and especially on how these constraints may potentially initiate consequences on broader economic outcomes.

A growing literature suggests that credit constraints are detrimental for employment (Bentolila et al., 2018; Berton et al., 2018; Fabiani et al., 2015; Gerlach-Kristen et al. 2017; Izquierdo et al., 2017; Linehan et al., 2015; Poulsen and Westergaard-Nielsen, 2017; Siemer, 2015). Yet, caution is required as: i) adequately controlling for the endogeneity of credit constraints remains challenging, and ii) existing studies do not always rely on direct information to identify whether firms are credit-constrained or not. Furthermore, many important questions regarding the nexus between credit shortages and employment still deserve to be investigated.

Very little is known regarding the various strategies that might be implemented by firms to reduce employment when credit is lacking. Most papers focus on total employment. However, employment could be adjusted at the extensive margin and/or at the intensive margin. At the extensive margin, firms could rely on individual/collective layoffs but also on other mechanisms such as early retirement schemes. In addition, some workers might be more at stake than others. A few recent studies for Southern European countries (Bentolila et al., 2018; Berton et al. 2018; Fernandes and Ferreiras, 2017) indeed suggest that temporary workers have been more affected than permanent ones. Evidence on whether creditconstrained firms are more likely to adjust employment at the intensive margin, e.g. by reducing working hours, is also very thin. The study of Fabiani et al. (2014) is one of the rare exceptions addressing this issue. It confirms the dual nature of the European Union, i.e. that firms which adjusted their labour costs following the Great Recession did so mainly by laying off temporary workers and reducing working hours.

The role of moderating factors in explaining the labour demand decisions of creditconstrained firms is also quite under-researched. Most studies focus on all firms independently of their size. However, a growing number of papers suggest that employment effects of credit shortages are likely to be stronger among SMEs (Balduzzi et al., 2017; 
Chodorow-Reich, 2014; Duygan-Bump et al., 2015; Popov and Rocholl, 2018; Siemer, 2014).

For Italy, Balduzzi et al. (2018) pinpoint the role of firms' age, while Berton et al. (2018) show that employment effects are more pronounced among less productive and more levered firms. The role of product demand and competition has been tested by Fabiani et al. (2014). Their results suggest that firms facing a credit drain are significantly more likely to cut labour costs when simultaneously hit by a drop in their sales and/or when operating in more competitive sectors. Overall, these studies illustrate the vast heterogeneity of firms' reactions to credit shocks according to their internal characteristics and the features of the markets on which they operate. Yet, evidence on these interaction effects is still too limited. More research is thus needed to improve our understanding of the mechanisms at play and to facilitate sound decision making in episodes of credit crunch.

Our paper takes advantage of access to detailed matched bank-firm data to investigate whether and how employment decisions of small- and medium-sized enterprises (SMEs) have been affected by different types of credit constraints during the European sovereign debt crisis. To do so, we combine data from the third wave of the Belgian Wage Dynamics Survey, covering the period 2010-2013, with confidential data from the Central Corporate Credit Register from the National Bank of Belgium (NBB). As in Chodorow-Reich (2014), variability in banks' financial health is used as an exogenous determinant of firms' access to credit. More precisely, firms' credit constraints during the 2010-2013 period are instrumented by the change in their main banks' loan supply before and after the 2008 financial crisis. Our prior is that firms borrowing money from pre-crisis less healthy banks (i.e. banks whose loan supply was most affected by the crisis) had a higher likelihood to be affected by a credit constraint during the 2010-2013 period, and as a consequences, had to reduce employment more substantially over that period than clients of more healthy banks.

Belgium is a particularly interesting case study. It has been severely hit by the 2008 financial crisis. Three of the country's largest banks - Fortis, Dexia and KBC - were bailed out, sold off and/or nationalised. This generated a considerable pressure on business funding (Bonnet et al., 2016; Piette and Zachary, 2015). It also led to a significant drop in employment, especially in the industry and the construction sector where respectively 47,000 and 50,000 jobs have been cut during the first year of the crisis. However, overall employment has been less affected in Belgium than in some neighbouring countries such as France, the Netherlands and also in the EU28 (see Figure 1). During the initial stage of the crisis (2008-2010), the Belgian labour market has also been characterised by a sharp decline in hourly productivity and average working hours (Cornille, 2015). Various flexibility 
mechanisms contribute to explain this phenomenon. The system of temporary lay-off allowances notably played an important role. These allowances 'provide a framework in which employers can adjust employees' working time in response to a variety of external circumstances including economic reasons, with the state mitigating the impact on employee remuneration via the state unemployment benefit system' (Hurley, 2010). ${ }^{1}$ The number of beneficiaries from those allowances increased from around 120,000 before the 2008 crisis to more than 210,000 in 2009 (ONSS, 2018). This system thus enabled many employers to adjustment their workforce along the intensive margin, and accordingly to avoid a great number of lay-offs. At the same time, domestic employment has also been supported by intensive creation of subsidised jobs, especially in the business services sector under the services voucher system.

\section{[Insert Figures 1 and 2 about here]}

A shown in Figure 2, the persistence of the crisis nevertheless led to a sharp decrease in employment between 2011 and 2013, except in the business services sector (notably due to the above-mentioned services voucher system). The decline was again largest in the industry and the construction sector: around 100,000 and 30,000 jobs have respectively been cut in these sectors between 2011 and 2013. Employment also decreased by more 20,000 units in the trade, transport and HORECA sector over the 2010-2013 period. The stronger deterioration in employment during this period can be explained as follows. After having intensively used temporary lay-offs during the initial phase of the crisis, companies, facing deteriorating prospects and financial positions due to persistently stagnating activity, eventually had to reduce their workforce. ${ }^{2}$ Furthermore, the temporary lay-off system was adjusted to prevent misuse. This said, it still benefitted to almost 170,000 workers in 2013 . Accordingly, it also enabled to save many jobs during the sovereign debt crisis.

To sum up, while firms' access to credit has been under strong pressure in Belgium, employment adjustment along the extensive margin has been significant (especially in the industry and construction industry), though fairly moderate in EU perspective. Hence, the role

\footnotetext{
${ }^{1}$ Eligibility for these allowances, traditionally restricted to blue-collar workers, has been extended to whitecollars in the Law of 19 June 2009 as part of a series of anti-crisis measures.

${ }^{2}$ As highlighted by Degryse et al. (2017), employment stickiness following bank-loan supply shocks can also be explained by the strictness of the Belgian employment protection legislation, particularly in the case of collective dismissals. The latter is indeed likely to reduce job separation rates, to foster employment adjustment along the intensive margin, but also to increase the lag between the decision to lay off workers and the actual change in the number of employees.
} 
of credit constraints in explaining SMEs employment decisions in this specific context deserves to be investigated. Moreover, since the relative preservation of total employment has been attributed to various flexibility mechanisms (including temporary lay-off allowances), focusing on the multiple channels by which credit-constrained SMEs may have had adjusted their labour input is of particular interest (Abraham et al., 2014).

Our data enable us to estimate and compare the employment effects of different types of credit constraints. More precisely, we test whether employment effects vary according to: i) the type of loan application that was denied (i.e. loans to finance working capital, investments and/or debt), and ii) whether firms faced 'quantitative' or 'cost' credit constraints (i.e. whether credit was not available or whether the conditions to borrow money were too onerous). We also examine the role of two moderating factors, namely demand shocks and product market competition. Theoretically, we expect employment consequences of credit constraints to be stronger among SMEs operating in strong competitive environments and/or hit by a negative demand shock. Finally, we investigate in greater depth the different strategies that might be implemented by credit-constrained firms to adjust employment. We first distinguish between the adjustment of labour at the extensive and intensive margins. Next, we study the different channels that can be used by firms to procure these adjustments.

The remainder of this paper is organised as follows. A literature review is provided in the next section. Sections 3 and 4 describe our data and estimation strategy. Descriptive statistics and econometric results are presented in sections 5 and 6 . The last section concludes.

\section{Review of the literature}

A large literature examines the economic consequences of financial constraints. Interest in this issue has become particularly critical since 2008. Indeed, the Great Recession and subsequent European sovereign debt crisis increased the need to better understand how firm's real decisions are affected by a financial crisis and the role of firms' access to credit in boosting economic recovery. Given that the crisis sparked a huge increase in unemployment rates among many advanced economies, a growing number of papers focuses on the extent to which firms' credit constraints and employment policies have been interconnected since 2008 .

Empirical contributions examining the employment consequences of credit constraints with data from before the Great Recession include most notably Hernando and MartinezCarrascal (2008). Relying on balance sheet data relative to Spanish firms over the period 1985-2001, their GMM-system estimates show that firms facing high financial pressure 
(assed through firms' debt burden, indebtedness and profitability) have substantial lower employment growth rates. The authors control for the endogeneity of firms' financial position using internal instruments (i.e. lagged values of explanatory variables in levels and firstdifferences, respectively). Nickell and Nicolitsas (1999) also examined the impact on employment of increases in firm-level financial pressure. Using accounts data for a sample of U.K. manufacturing companies over the period 1972-1986, they find that the ratio of interest payment to cash flow (i.e. financial pressure) has a large negative effect on employment. This effect is identified using as an instrument firms' lagged debt burden interacted with the current shift in the yield on Treasury bills. Also focusing on balance sheet data from U.K. manufacturing companies, but for the 1994-2004 period, Spaliara (2009) finds that the capital-labour ratio is sensitive to firm-specific characteristics (i.e. cash flow, leverage, collateral and interest burden), especially in firms that are more likely to face a financing constraint. Accordingly, the authors conclude that U.K. authorities should help constrained firms to avoid shortage of credit (especially during bad economic times) so as to preserve jobs. This conclusion is drawn on the basis of a GMM first-differenced estimator. Endogeneity is thus controlled for using internal instruments (lagged levels of explanatory variables).

A growing literature examines the impact of credit constraints on corporate employment decisions since the Great Recession, i.e. using data from 2008 onwards. Campello et al. (2010), for instance, surveyed 1,050 Chief Financial Officers (CFOs) in the U.S., Europe and Asia to assess whether or not their corporations were credit-constrained in 2008 and, in turn, to study if these financial constraints had any real corporate effects, notably on employment. Using a matching estimator approach, i.e. pairing-up constrained and unconstrained companies facing similar economic circumstances, they find that financially constrained firms planned to cut more employment relative to financially unconstrained firms during the crisis. Although quite appealing, their matching approach applied to survey data may not be completely 'bullet-proof' to potential endogeneity issues. Indeed, 'CFOs may by themselves not be able to separate economic from financial effects when responding to a survey' (Campello et al., 2010: 471). Duygan-Bump et al. (2015) investigated the link between small business lending and unemployment during the Great Recession in the U.S.. Combining information from the Current Population Survey with firms' financial data for 2007-2009, they find that workers in small firms were more likely to lose their jobs than their opposite numbers in large firms, but only if they were employed in more financially distressed industries. Identification of credit supply effects is achieved through the use of industry-level 
measures of external finance dependence. Siemer (2014) also suggests, on the basis of detailed firm-level panel data for 2007-2009, that financial constraints in the U.S. were more detrimental to employment growth in smaller firms. As in Campello et al. (2010), his identification strategy relies on the comparison of estimates for sectors with high and low external finance dependence. The study of Fabiani et al. (2015), based on harmonised data for 9 European countries for 2007-2009, shows that permanent and temporary employees' likelihood to be dismissed was significantly bigger among credit-constrained firms. Endogeneity of credit constraints is not explicitly addressed in their analysis. Another study investigating the effects of the 2008-2009 financial crisis on firms' employment decisions in terms of job contracts is that of Fernandes and Ferreira (2017). Pre-crisis variation in financial variability across industries is used for identification. Estimates, based on Portuguese linked employer-employee data, show that firms belonging to more financially constrained sectors hired a larger share of temporary workers after the crisis. This is also supported by workerlevel estimates suggesting that workers, employed by firms requiring more external funding, were more likely to be hired on a temporary contract after the crisis.

Our paper is more closely related to the relatively few existing studies employing matched bank-firm data to investigate how shocks to bank balance sheets affected firms' employment decisions since 2008. The latter notably include the study of Chodorow-Reich (2014) for the U.S.. The author shows that credit-constrained SMEs were significantly more likely to reduce employment than their non-credit-constrained counterparts. In contrast, they find no significant effect of credit constraints on employment among larger firms. Firm credit constraints are instrumented by lenders' financial health, i.e. the change in the loan supply to each of their borrowers before and after the Great Recession. The analysis of Popov and Rocholl (2018), based on detailed German data, shows that employment decline has been significantly stronger among firms (especially smaller ones) that have been hit by a credit constraint. Their instrument for firm credit constraints is a dummy indicating whether or not the firm had a credit relationship with a bank affected by the U.S. subprime mortgage crisis. Gerlach-Kristen et al. (2015) also find a significant negative effect of credit constraints on the employment level of SMEs in the Irish economy. Their instrumental variables for credit constraints include: i) two binary indicators for the ownership of the bank, and ii) a dummy taking the value one if the firm believed - on the basis of factors not related to her own experience - such as media reports, lobby groups or business peers - that banks were not lending. Using rich Spanish matched bank-firm data for the period 2006-2010, Bentolila et al. (2018) compare the employment performance of firms with pre-crisis loans from weak banks 
to that of comparable firms with pre-crisis loans from healthy banks. ${ }^{3}$ Controlling for various econometric issues including selection effects, the authors find that weak-bank attachment caused employment losses of about 2.2 percentage points, which accounts for almost a quarter of total employment decline among exposed firms. Their results also show that credit constraints were relatively more important in bringing firms to cut jobs than in forcing them to close down. This outcome is consistent with the 'quick labour shedding' hypothesis (Bentolila et al., 2012), namely that the large share of pre-crisis temporary contracts in Spain enabled many firms to downsize rapidly and hence to survive the Great Recession. According to Berton et al. (2018), one quarter of total employment reduction between 2008 and 2012 in Veneto, a large Italian region, is also due to the contraction in credit supply. Their detailed matched bank-firm data, among other advantages, enable them to construct an exogenous firm-specific time-varying measure of bank credit supply and to investigate the diversity of employment outcomes across firms, workers and job contracts. Estimates show that low skilled and temporary workers have been most affected. The same holds true for more levered and less productive firms. Another paper focusing on the Italian experience is that of Balduzzi et al. (2018). Exploiting two shocks (i.e. the 2008 financial crisis and the sovereign debt crisis), the authors test if changes in banks' market valuations affected client firms' real decisions. Their findings show that increases in banks' CDS spreads, and decreases in their equity valuations, led younger and smaller firms' to cut investment, employment and borrowing. Degryse et al. (2017) investigate the impact of bank-loan supply shocks on firm outcomes and bank risk-taking using bank-firm matched credit information from Belgium for the period 2002-2012. Among other results, the authors find that firms borrowing money from banks facing a negative supply shock experienced a significantly lower growth rate of their total assets, fixed assets and full-time equivalent number of employees ${ }^{4}$, particularly (but not exclusively) during periods of financial distress. Banks that have been facing a more positive (negative) supply shock are also found to have made less (more) prudent decisions relative to the riskiness of their portfolio.

In sum, a growing number of papers suggest that the 'sharpest credit shortage in nearly a century' (Campello et al., 2010: 486) has been quite harmful for employment. Yet, current evidence leaves the door open for further developments. Besides the fact that adequately controlling for the endogeneity of credit constraints remains challenging, a first important

\footnotetext{
${ }^{3}$ The authors have access to information on almost all existing and newly-granted loans to non-financial firms but also on loan applications from non-current clients and on whether they have been granted.

${ }^{4}$ Yet, results in terms of employment adjustment are found to be somewhat weaker than for the two other outcome variables.
} 
avenue for research but also for policy boils down to get a better understanding of moderating factors, and especially of how the nexus between credit shortage and employment is affected by product market demand and competition. Another under-researched issue refers to the channels through which credit-constrained firms might adjust their labour input, e.g. at the extensive or intensive margin. This is an important question for policymakers as adjustment at the intensive margin (e.g. through the various short-time and temporary layoff schemes that have been made available to firms in many advanced economies during the crisis) contributes to mitigate job destruction. The objective of this paper is to improve our comprehension of these key issues taking advantage of access to detailed matched bank-firm data, for a representative sample of SMEs in Belgium, which: i) include direct information on several types of credit constraints and employment adjustment strategies, alongside various covariates for workforce composition, firm characteristics and other aspects of the economic environment, and ii) enable us to instrument firms' credit constraints during the 2010-2013 period by the change in their main banks' loan supply before and after the 2008 financial crisis.

\section{Data}

Our empirical analysis is based on a Belgian firm-level survey undertaken within the Wage Dynamics Network (WDN) of the ESCB (i.e. the European System of Central Banks). This survey (i.e. the so-called $3^{\text {rd }}$ wave of the Belgian WDN survey) has been conducted by the National Bank of Belgium (NBB) in June and September 2014. It includes questions on firms' perception of the nature of the changes in the economic environment that have resulted from the sovereign debt crisis, their reactions to these changes and the role of financial constraints. ${ }^{5}$ More precisely, it broaches the changes that occurred in the economic environment during the course of the 2010-2013 period, by identifying the type and intensity of the shocks that might have affected companies. It also provides detailed information on the structure and adaptation of labour forces in the companies questioned.

The WDN survey was sent out by surface mail, with the option of using an electronic format version. In total, 991 firms participated in the survey, giving a response rate of $21 \%$. Given the length of the questionnaire, this can be considered as satisfactory. In terms of response behaviour by questions, the response rate is on average higher than $95 \%$ and varies

\footnotetext{
${ }^{5}$ A copy of the questionnaire, used to gather these detailed cross-sectional data, can be found on the NBB's website (see www.nbb.be/en/wage-dynamics-network-wdn-3).
} 
between $100 \%$ and $83 \%$. The answers are consistent with information from other sources (Cornille, 2015). Our final sample, excluding 136 firms due to missing replies, contains 855 firms. It is representative of all firms employing at least 5 workers and less than 250 workers ${ }^{6}$ in the manufacturing and building industries, trade and business services. ${ }^{7}$ Sectors covered by the survey together account for 52\% of employment in Belgian firms (excluding selfemployed).

To identify the effect of credit constraints on employment, endogeneity issues have to be addressed. Therefore, we rely on two-stage least squares (2SLS) and bivariate probit models. Following existing research (Bentolila, 2018; Chodorow-Reich, 2014), our instruments are drawn from the characteristics of the firms' main bank (see next section for more details). This information is not available in the WDN survey. Therefore, the latter has been merged with data from the Central Corporate Credit Register (CCCR) from the NBB. This merger reduces the number of firms in our sample by approximately one-third, i.e. from 855 to around 522 firms. This drop in sample size derives from the fact that a certain number of firms have no bank credit at all, have only bank credits outside Belgium, or are part of bigger corporations which have their own bank credits. The magnitude of the attrition is coherent with more aggregate evidence from credit register data and the distribution of firm size in our sample (Piette and Zachary, 2015). The impact of attrition on the composition of our sample and hence on its representativeness is very limited. Indeed, as discussed below, descriptive statistics remain remarkably stable after sample reduction.

\section{Estimation strategy}

\subsection{Baseline specification}

Our empirical investigation is made of two steps. First, we test the employment consequences of credit constraints with a linear probability model (LPM). More precisely, we estimate by ordinary least squares (OLS), the following firm-level equation:

\footnotetext{
${ }^{6}$ Although the sample design did not contain an explicit upper threshold for firm size, in practice almost $99 \%$ of firms that were surveyed employed less than 250 workers. Given our focus on SMEs, firms employing 250 workers or more (i.e. about 10 firms in the initial sample) have been dropped.

7 To make results representative of the total population of sectors considered, statistics (reported in the next sections) are computed using employment-adjusted weights. For more details on the sample design and its representativeness see Cornille (2015).
} 
The dependent variable in equation (1) is a dummy taking the value 1 if the firm $i$ needed to significantly reduce its labour input or to alter its composition between 2010 and $2013^{8}$, and 0 otherwise. ${ }^{9}$ The main explanatory variable $C C_{i}$ is a binary variable taking the value 1 if the firm has been affected by a quantitative credit constraint between 2010 and 2013 (namely, if the firm declared that credit was not available to finance working capital, to finance a new investment or to refinance its debt) and 0 otherwise.

Firm-level covariates are contained in the vector $X_{i}$. In selecting these covariates, we draw on existing research which suggests to control for workforce composition, firm characteristics and other aspects of the economic environment (Fabiani, 2016, GerlachKirsten et al., 2015). Accordingly, $X_{i}$ includes the share of the workforce within firm $i$ that has at most 5 years of tenure; the proportion of high-skilled workers among both blue- and white collars (i.e. ISCO codes 1-3 and 7-8); the sectoral affiliation (4 dummies), age (in years) and size (i.e. the total number of employees) of the firm; a dummy taking the value 1 if the degree of competition on the market for the firm's main product/service is very severe, and 0 otherwise (i.e. if it is severe, moderate or weak); and a binary variable taking the value 1 if the level of demand for the firm's products/services has been decreasing moderately or strongly during 2010-2013, and 0 otherwise (i.e. if it remained unchanged or increased).

OLS estimates of qualitative response models, such as equation (1), are generally considered to be less reliable than those obtained by probit, especially when predicted probabilities are not close to 0.5 (Wooldridge, 2002). This is because the underlying conditional expectation function (CEF) is only roughly linear in the middle. Moreover, LPM estimates are limited by the fact that they are not bounded to the unit interval. More precisely, Horrace and Oaxaca (2006) demonstrate that the potential bias associated to the LPM is proportional to the share of LPM predicted probabilities that fall outside the unit interval. Hence, to check the robustness of our results, we examine the concordance of LPM estimates with marginal effects from a probit model.

\footnotetext{
${ }^{8}$ Put differently, if the firm had to adjust its labour force at the extensive and/or intensive margin.

${ }^{9}$ The specific question in the WDN survey to identify whether a firm adjusted its labour input (at the intensive and/or extensive margin) is the following: "During 2010-2013 did you need to significantly reduce your labour input or to alter its composition?". Firms were asked to reply to this question by 'yes' or 'no'. This is why our dependent variable is binary and not continuous as in some other papers (e.g. Bentolila et al., 2018; Berton et al., 2018).
} 


\subsection{Instrumental variables and exclusion restrictions}

When studying the employment consequences of credit constraints, an important econometric issue that has to be addressed is endogeneity. This issue may notably derive from reverse causality. Indeed, firms might reduce their labour input because they faced a credit constraint. However, it is also possible that firms don't get the required funding because they have financial difficulties, which led them in first instance to lay off workers. To control for potential endogeneity, we first rely on two-stage least-squares (2SLS). This method consists in finding instrumental variables (IV), which are at the same time highly correlated with the endogenous variable (i.e. credit constraints) and uncorrelated with firm-level changes in employment. Our main IV is the \% change in the number of loans made by the firm's $i$ main bank to all borrowers other than firm $i$ before (i.e. October 2005 - June 2007) and after (i.e. October 2008 - June 2011) the 2008 crisis. $^{10,11}$ This instrument, similar to the one used by Chodorow-Reich (2014), reflects the financial health of the firm's main bank. The bigger, i.e. the more positive, the value of this variable, the healthier the lender is expected to be. We thus use the variability in lender's health as an exogenous determinant of the firm's access to credit. Our prior is that firms borrowing money from pre-crisis less healthy lenders had a higher likelihood to be affected by a credit constraint during the crisis, and as a consequence, had to reduce their labour input more substantially than clients of more healthy banks. Moreover, to account for potential non-linearities, we also include the inverse value of this IV in the first step of our estimation procedure. Finally, to further capture the financial health of the lender, we also included dummies identifying the main bank of each firm.

Various diagnostic tests are performed when running 2SLS regressions. The latter explore respectively the acuteness of the endogeneity issue in our data and the quality of our instruments. More precisely, we first compute the Kleibergen-Paap statistic for weak identification. It is a Wald $F$ statistic testing whether the excluded instruments are sufficiently correlated with the endogenous regressor. The null hypothesis is that the instruments are weak. Next, we examine the validity of our instruments with Hansen test of overidentifying restrictions. Under the null hypothesis the instruments are valid, i.e. uncorrelated with the error term. Finally, we compute an endogeneity test with the null hypothesis that the credit

\footnotetext{
${ }^{10}$ To take bank size into account, this \% change is normalised by the number of loans made by the firm's main bank before the 2008 crisis.

${ }^{11}$ To avoid that the measurement period of our IV overlaps with that of our endogenous variable, as a robustness test, we re-estimated our benchmark equation using as IV the change in firms' main bank loan supply between October 2005 - June 2007 and October 2008 - June 2009 (instead of June 2011). 2SLS and bivariate probit estimates, available on request, remain very stable and leave our conclusions unaffected.
} 
constraint can actually be considered as exogenous. The test is based on the difference of two Sargan-Hansen statistics: one for the equation in which the credit constraint is treated as endogenous, and one in which it is treated as exogenous. If the null hypothesis of this test cannot be rejected, then instrumentation is actually not necessary.

The traditional approach to control for endogeneity is the 2SLS estimation. However, since both the dependent variable and the potentially endogenous variable are binary the use of 2SLS might be criticized. Therefore, we also use a bivariate probit model to check the robustness of our results. The relevance of the bivariate model compared to the single probit model is verified with a Wald test examining whether the correlation of the error terms of the two probit regressions is significantly different from zero. If the test rejects the null hypothesis of no correlation between the two error terms, the bivariate probit is recommended.

\subsection{Heterogeneous employment effects}

To gain a better understanding of the potentially heterogeneous effects of credit constraints on the adjustment of employment within firms, a series of complementary tests are performed.

Our benchmark specification, i.e. equation (1), focusses on the employment effects of quantitative credit constraints, i.e. whether credit was available to a firm or not. Yet, the WDN survey also contains information on cost constraints, i.e. whether credit was available but the conditions (interest rates and other contractual terms) were too onerous (Cost constraint $_{i}$ ). A first complementary test thus aims to examine if the employment consequences of quantitative and cost constraints are comparable in terms of magnitude and significance.

The literature suggests a number of channels through which credit constraints may affect the employment decisions of firms (Nickell and Nicolitsas, 1999; Spaliara, 2009). A first channel is credit availability to finance working capital. As working capital loans are meant to finance everyday expenses related to the daily operation of a business (e.g. to cover unexpected costs, pay employee wages), they are very likely to have a direct impact on the firm's employment decisions. Another channel is credit to finance investments. If a company cannot borrow as much as she wants to invest in capital goods, she is likely to recruit less workers to complement the new fixed asset. This is the expected outcome if one assumes that capital and labour are complementary inputs, i.e. that the capital-labour ratio remains relatively stable. For higher degrees of substitutability between labour and capital, the 
outcome may be different. Indeed, the firm could than choose to decrease its capital-labour ratio by hiring more workers than initially planned as a compensation strategy. A third channel is credit availability to refinance debt. Firms willing to refinance their debt may want to take advantage of a better interest rate (reduced monthly payment or term) or to reduce/alter the risk relative to their debt (e.g. by switching from a variable-rate to a fixed-rate loan). However, it may also be a strategy for financial distressed borrowers to restructure their debt, i.e. to free up cash (e.g. by negotiating lower monthly payments for a longer term). Most firms that are denied credit to refinance their debt are probably in the second situation. Hence, the employment consequences of this type of credit constraint are likely to be negative. To sum up, our second complementary test aims to examine how these different channels of credit constraints affect firms' employment responses. To do so, we break down WDN data on quantitative constraints by type of loan application that was denied credit, focusing on applications for working capital, new investments and debt refinancing.

Next, we investigate two potentially important moderators. On the one hand, we examine the role of demand shocks. More precisely, we test whether firms experiencing credit constraints had to adjust employment more substantially when they were hit concomitantly by a negative demand shock. To do so, we re-estimate equation (1) separately for: i) firms reporting a moderate or strong decrease in the demand for their main product/service, and ii) those whose demand remained unchanged or increased between 2010 and 2013. Clearly, we expect employment consequences of credit constraints to be stronger among the former group of firms. On the other hand, we test the moderating role of firms' product environment. To do so, we re-estimate equation (1) separately for: i) firms facing very severe competition on their main product/service market, and ii) those facing weak, moderate or severe competition. Traditional bargaining models, e.g. 'right-to-manage' or 'efficient bargaining' (Cahuc and Zylberberg, 2014), suggest that employment adjustment should increase with the elasticity of labour demand and the price elasticity of demand in the product market. Accordingly, we expect employment responses to be stronger among firm operating in more competitive markets. ${ }^{12}$

\footnotetext{
12 Theoretically, wage responses to credit constraints are also expected to be stronger in more competitive markets. Although this issue is beyond the scope of our paper, descriptive statistics from the WDN survey show that between 2010 and 2013 (a period characterised by near-zero inflation) only $0.6 \%$ (1.6\%) of firms cut basic wages (flexible wage components), while $33 \%$ of firms reduced their labour input. Overall, this suggests that if credit constraints have had any impact on the labour force in Belgium, it should be in terms of quantity rather than in terms of prices. This conclusion is not surprising in light of earlier findings showing the prevalence of strong real downward wage rigidity in Belgium (du Caju et al., 2012).
} 
Finally, we investigate in greater depth the different strategies that can be implemented by firms to adjust employment following a credit constraint. We first distinguish between the adjustment of labour at the extensive and intensive margins. Next, we study the different channels that can be used by firms to procure these adjustments. For the extensive margin, we focus in turn on: collective layoffs, individual layoffs, adjustment of temporary employment and early retirement. As regards the intensive margin, we examine respectively temporary layoffs (for economic reasons) and reductions of working hours (subsidised or not).

\section{Descriptive statistics}

Table 1 presents summary statistics for all variables included in our econometric analysis. Results show that $33 \%$ of firms in our sample reduced their labour input or had to alter its composition between 2010 and 2013. 31\% of firms declared they adjusted labour at the extensive margin, while $21 \%$ did so at the intensive margin. As regards channels to adjust labour at the extensive margin, $28 \%$ of firms reported that they relied on individual layoffs and $17 \%$ on temporary employment adjustment. Collective layoffs and early retirement schemes have been used by a much smaller proportion of firms (respectively, 1 and 8\%). To adjust labour at the intensive margin, firms heavily relied on temporary layoffs $(17 \%)$. In contrast, only $8 \%$ of firms decided to reduce working hours.

About credit constraints, $27 \%$ replied that they faced a quantitative constraint (i.e. credit was not available) and $23 \%$ a cost constraint (i.e. credit was available but the conditions - interest rate and other contractual terms - were too onerous). In addition, 16\% of firms responded they were denied credit to finance working capital or to refinance their debt, while $22 \%$ could not borrow money to make a new investment. Concerning workforce characteristics, results indicate that firms in our sample have on average $37 \%$ of workers with at most 5 years of tenure and $43 \%$ of high-skilled workers (among both white and blue collars). On average, firms employ 35 workers and have been established around 36 years ago. The sectoral distribution of firms is as follows: business activities (37\%), trade (29\%), manufacturing (16\%), construction (14\%) and financial intermediation (3\%). Regarding other aspects of the economic environment, statistics indicate that $52 \%$ of firms experienced a moderate or strong decrease in the demand for their products/services between 2010 and 2013, while $52 \%$ faced very severe competition on their main product/service market.

[Insert Table 1 about here] 
To address potential endogeneity, the WDN survey has been merged with data from the CCCR. As highlighted in section 3, this merger reduces the number of firms from 855 to 522. The impact of this attrition on the composition of our sample and hence on its representativeness is very limited. Indeed, most descriptive statistics reported in Appendix 1 remain remarkably stable. This said, a few differences can be highlighted. First, we find that firms are slightly smaller in the merged sample (the average number of employees decreases from 35 to around 30). Second, the share of firms that have experienced a quantitative credit constraint becomes somewhat bigger (it increases from 27 to 33\%). Finally, the share of firms operating in the financial intermediation sector drops from 3 to $0 \%{ }^{13}$ As highlighted in section 3, our sample is representative of firms employing between 5 and 250 workers in the manufacturing and building industries, trade and business services.

\section{Regression analysis}

\subsection{Benchmark estimates}

[Insert Table 2 about here]

OLS estimates of equation (1) are reported in the second column of Table 2 . They show that quantitative credit constraints have had a significant positive effect on the likelihood of firms to reduce their labour input between 2010 and 2013. ${ }^{14}$ The regression coefficient stands at 0.099. This implies that firms facing credit constraints were ceteris paribus $10 \%$ more likely to adjust their workforce downwards than their opposite numbers not facing such constraints. As a robustness test, we computed marginal effects from a probit regression. The latter, reported in the third column of Table 2, lead to the same conclusion. The magnitude and significance of the employment effects are indeed very similar when applying the OLS or probit estimators. Regression coefficients associated to covariates are also generally found to be significant. As anticipated, they notably show that firms experiencing a decrease in the demand for their product or facing strong competition on their market were more likely to reduce their labour force. Moreover, while the probability to adjust labour downwards appears

\footnotetext{
${ }^{13}$ Descriptive statistics for the instrumental variables (excluding restrictions) used in the 2SLS (bivariate probit) regressions are reported in Appendix 2.

14 The dependent variable in Table 2 is a dummy taking the value 1 if the firm needed to significantly reduce its labour input or to alter its composition between 2010 and 2013, and 0 otherwise.
} 
to be significantly bigger among firms employing a larger share of workers with less than 5 years of tenure, the opposite outcome is observed (in the probit regression) for firms with more high-skilled workers. These results are compatible with the idea that firms can more easily lay off workers when adjustment costs are lower, i.e. when workers' tenure and/or skills are more limited.

[Insert Table 3 about here]

Yet, these estimates should be taken with caution as endogeneity (due e.g. to reverse causality) could be an issue. To address this potential issue, we first re-estimated equation (1) with 2SLS using as instruments variables reflecting the financial health of firms' main bank (see section 4.2). Results are reported in the second column Table 3. The $p$-value associated to the endogeneity test is equal to 0.06 . This suggests that the null hypothesis of no endogeneity can be rejected at traditional probability levels, i.e. 2SLS estimates should be preferred to those obtained by OLS. Furthermore, we find that the test statistic for weak identification is statistically significant, which implies that our instruments are not weak. This is also illustrated by our first stage regression. Estimates, reported in the second column of Appendix 3, indeed show that most instruments are significant with the expected sign. More precisely, we find that the percentage change in the loan supply of the main bank of a firm (before and after the 2008 crisis $)^{15}$ decreases significantly the probability of that firm to be effected by a credit constraint. Put differently, results indicate that firms borrowing money from more healthy lenders before the Great Recession (i.e. banks whose loan supply was least affected by the crisis) had a lower likelihood to be credit constrained during the 2010-2013 period. We also find that many bank dummies are statistically significant. This again suggests that firms' difficulties to borrow money were at least partly driven by the severity of the financial distress of their main bank. Concerning the quality of our instruments, we further find that the $p$-value associated to the Hansen's $J$ overidentification test (see the second column of Table 3 ) is equal to 0.66 . This implies that our instruments are valid, i.e. we cannot reject the exogeneity of the latter.

As regards 2SLS regression coefficients, they again show that credit constraints have had a highly significant and positive effect on the probability that firms adjusted their labour

\footnotetext{
${ }^{15}$ As noted in section 4.2., the exact definition of this variable is as follows: \% change in the number of loans made by the firm's $i$ main bank to all borrowers other than firm $i$ before (i.e. October 2005 - June 2007) and after (i.e. October 2008 - June 2011) the 2008 crisis, normalized by the number of loans made by the firm's $i$ main bank before the crisis.
} 
input downwards between 2010 and 2013. More precisely, they indicate that firms facing credit constraints were ceteris paribus 51\% more likely to reduce their labour input. This estimate is bigger than the one obtained by OLS. Accordingly, it appears that employment effects of credit constraints are under-estimated when endogeneity is not controlled for. A similar finding is reported by Chodorow-Reich (2014: 41) using U.S. data.

This said, caution is required as it is generally admitted that bivariate probit estimates of qualitative response models are more reliable than those obtained by 2SLS, especially when predicted probabilities are not close to 0.5 . Hence, as a robustness test, we re-estimated our benchmark equation with a bivariate probit estimator using the same covariates and excluding restrictions (i.e. instruments) as in our 2SLS regression. Results, reported in the third column of Table 3, first show that bivariate probit estimates should be preferred to simple probit ones. The Wald test statistic is indeed highly significant ( $p$-value equal to 0.00 ). Furthermore, estimates confirm the positive and significant effect of credit constraints on employment adjustment. The marginal effect from our bivariate probit regression is equal to 0.40 , which is relatively close to our 2SLS estimate.

In sum, our regression analysis clearly highlights that credit matters. We find indeed that firms borrowing money from pre-crisis less healthy banks were more likely to be affected by a credit constraint and, in turn, to adjust their labour input downwards than pre-crisis clients of more healthy lenders.

\subsection{Heterogeneity of employment effects}

In this section, we test the sensitivity of our findings by: i) examining the employment effects of cost rather than quantitative credit constraints, ii) differentiating quantitative constraints by type of loan application that has been denied credit, iii) investigating the moderating role of demand shocks and product market competition, and iv) exploring the different strategies that have been implemented by credit-constrained firms to adjust employment (see discussion in section 4.3).

\section{[Insert Table 4 about here]}

Results in Table 4 show probit and bivariate probit estimates relative to cost credit constraints, namely a dummy variable taking the value one if the firm declared that credit was available between 2010 and 2013 but that the conditions (interest rates and other contractual 
terms) were too onerous, and zero otherwise. Independently of the estimator adopted, regression coefficients associated to this variable are always found to be insignificant at standard probability levels. This outcome suggests that firms that had to cope with more stringent credit conditions (i.e. to face cost credit constraints) were still able to borrow enough money, at sufficiently good terms and conditions, so as to keep employment unaffected. It thus appears that cost constraints have had a much less detrimental impact on employment than quantitative constraints.

\section{[Insert Table 5 about here]}

Regressions examining the employment effects of quantitative credit constraints according to the type of loan application that was denied (i.e. loans to finance working capital, new investments and debt, respectively) are reported in Table 5. Bivariate probit estimates (which, according to Wald $\chi^{2}$ statistics, should be preferred to simple probit ones) indicate that firms that have had a credit constraint were, depending on the type of denied credit, between 41 and $49 \%$ more likely to adjust their workforce downwards than their opposite numbers not affected by such constraint. The relative size of employment effects thus appears to be quite similar across types of loan applications. Yet, marginal effects are found to be significantly, though modestly, bigger for credit shortages associated in turn to debt refinancing, working capital and new investments.

[Insert Table 6 about here]

In order to test the role of demand shocks in explaining employment effects of credit constraints, we re-estimated equation (1) according to whether or not firms reported a decrease in the demand for their products/services between 2010 and 2013. ${ }^{16}$ Probit and bivariate estimates, reported in Table 6, reveal that credit constraints are only statistically significant among firms that experienced a negative demand shock. More precisely, we find that credit constrained firms, affected by a decrease in their demand, were ceteris paribus

\footnotetext{
16 The specific question to identify demand shocks in the WDN survey is the following: "How did the level of demand for your products/services evolve during 2010-2013?" Firms could choose one of the following answers: strong decrease, moderate decrease, unchanged, moderate increase, or strong increase. In the regressions reported in the manuscript, this variable has been recoded as a dummy taking the value one if the firm declared having experienced a moderate or strong decrease in demand, and zero otherwise (i.e. if demand remained unchanged or increased). However, some robustness tests have been performed, notably by recoding the variable in three categories: a) strong or moderate decrease, b) unchanged, and c) moderate or strong increase. The latter corroborate our conclusions.
} 
$46 \%$ more likely to adjust their labour input downwards. On the opposite, estimates show that credit constraints had no significant employment effects among firms with a stable or increasing demand. Hence, we may conclude that access to credit is mostly important for employment when demand is falling.

[Insert Table 7 about here]

Moreover, to examine the role of firms' product environment, we re-estimated equation (1) according to whether or not firms were facing very severe competition on their main product/service market between 2010 and 2013. ${ }^{17}$ Estimates, shown in Table 7, clearly indicate that credit constraints had a substantially stronger impact on employment among firms operating in very competitive markets. We find indeed that credit-constrained firms were ceteris paribus 36\% more likely to reduce their labour input than not credit-constrained ones when facing very severe competition. In contrast, credit constraints are found to have a non-significant effect on employment among firms operating in more weakly competitive markets. In line with theoretical expectations, our findings thus suggest that credit constraints matter for employment especially among firms facing strong product market competition. ${ }^{18}$

Finally, we explored the different strategies that have been implemented by creditconstrained firms to adjust employment. To do so, we first re-estimated equation (1) using as outcome variable employment adjustment along the extensive and intensive margins, respectively. When focusing on the extensive margin, the dependent variable is a dummy taking the value 1 for firms that relied (marginally, moderately or strongly) on i) collective layoffs, ii) individual layoffs, iii) non-renewal of temporary contracts at expiration and/or reduction of agency work, and/or iv) early retirement schemes between 2010 and 2013; and 0 otherwise. When exploring employment adjustment along the intensive margin, the dependent variable is a dummy taking the value 1 for firms that relied (marginally, moderately or strongly) on i) temporary layoffs (for economic reasons), and/or ii) subsidised and/or non-

\footnotetext{
17 The specific question to identify product market competition in the WDN survey is the following: "How would you describe the degree of competition on the main markets for your main product (or main activity or services)?" Firms could choose one of the following answers: weak, moderate, severe, or very severe. In the regressions reported in the manuscript, this variable has been recoded as a dummy taking the value one if the firm declared experiencing very severe competition, and zero otherwise (i.e. if competition is weak, moderate, or severe). However, some robustness tests have been performed, notably by distinguishing firms facing respectively: a) severe or very severe competition, and b) weak or moderate competition. The latter support our conclusions.

${ }^{18}$ Given the cross-sectional nature of our data, testing for the moderating role of demand shocks and product market competition using an alternative strategy based on a combination of firm, time and industry fixed effects cannot be applied.
} 
subsidised reduction of working hours (including reduction of overtime) between 2010 and 2013; and 0 otherwise. To get a better understanding of credit-constrained firms' strategies to reduce their labour input, equation (1) has also been re-estimated using as outcome variable each of these (extensive and intensive) adjustment channels separately.

[Insert Table 8 about here]

Estimates regarding employment adjustment at the extensive margin are reported in columns 2 and 3 of Table 8. Bivariate probit estimates (which, according to the Wald test should be preferred to single probit ones) indicate that credit-constrained firms were ceteris paribus $40 \%$ more likely to adjust employment at the extensive margin than non-constrained firms. Among the various channels that can be used to attain this goal, results reported in Table 9, show that credit-constrained firms essentially relied on individual layoffs, early retirement schemes and reduction of temporary employment. In contrast, we find no significant effect of credit constraints on collective layoffs.

[Insert Table 9 about here]

The impact of credit constraints on employment adjustment along the intensive margin is shown in columns 4 and 5 of Table 8 . Estimates are found to be highly significant. However, their magnitude is on average lower than in the extensive margin regressions. Indeed, the marginal effect associated to the bivariate probit regression (which should be preferred to single probit one) stands at 0.30 . Results in Table 10 provide more details on the policies that have been implemented by credit-constrained firms to adjust employment at the extensive margin. They show that the latter were significantly more likely to rely on temporary layoffs (for economic reasons) than their non-constrained opposite numbers. In contrast, firms' likelihood to reduce working hours appears unrelated to whether or not they had a credit constraint.

[Insert Table 10 about here] 


\section{Conclusion}

While the outbreak of the Great Recession and the subsequent European sovereign debt crisis caused much economic hardship, it also provided a unique opportunity to gain a better understanding of how corporate employment decisions are affected by credit shortages in bad economic times. This paper takes advantage of access to detailed matched bank-firm data to investigate whether and how employment decisions of SMEs have been affected by different types of credit constraints during the sovereign debt crisis. To do so, we combined detailed data from the third wave of the Belgian Wage Dynamics Survey, covering the period 20102013, with confidential data from the Central Corporate Credit Register from the National Bank of Belgium.

Our regression analysis clearly shows that credit matters. Two-stage least squares (2SLS) and bivariate probit estimates indeed suggest that SMEs borrowing money from precrisis financially less healthy banks were significantly more likely to be affected by a credit constraint and, in turn, to adjust their labour input downwards than pre-crisis clients of more healthy banks. More precisely, we find that credit-constrained SMEs were ceteris paribus $40 \%$ more likely to reduce their workforce than their opposite numbers not facing such constraints. This outcome, associated to quantitative credit constraints, is robust across types of loan applications that were denied credit (i.e. applications to finance working capital, debt or new investments). Cost constraints, on the opposite, are found to have had little impact on firms' employment decisions.

Furthermore, estimates show that employment consequences of quantitative credit shortages are strongly contingent on the environment in which firms operate. Results indeed indicate that credit constraints have been essentially detrimental for employment among SMEs experiencing a negative demand shock or facing very severe product market competition. This outcome is in line with traditional bargaining models predicting that employment adjustment increases with the elasticity of labour demand and the price elasticity of demand in the product market.

Finally, our estimates uncover the strategies that have been adopted by creditconstrained firms to adjust their labour input. They clearly show that credit shortage has been a key factor pushing SMEs to reduce their workforce at the extensive margin, and in particular to rely on individual layoffs, early retirement schemes and reduction of temporary employment. However, estimates also show that credit-constrained SMEs have been significantly more likely to adjust employment at the intensive margin, especially through the 
use of temporary layoff allowances, than their non-constrained counterparts. This outcome is quite interesting as it suggests that temporary layoff schemes have played a significant role in mitigating the employment effects of the financial crisis in Belgium. Put differently, it adds to a growing literature indicating that short-time compensation, i.e. pro-rated unemployment benefits for workers whose hours are reduced for economic reasons, may effectively contribute to save jobs during recessions (Abraham and Houseman, 2014; Hurley, 2010).

\section{References}

Abraham, K. and Houseman, S. (2014), "Short-time compensation as a tool to mitigate job loss? Evidence on the U.S. experience during the recent recession", Industrial Relations, 53(4): 543-567.

Balduzzi, P., Brancati, E. and Schiantarelli, F. (2018), "Financial markets, banks' cost of funding, and firms' decisions: lessons from two crises", Journal of Financial Intermediation, 36: 1-15.

Bentolila, S., Cahuc, P., Dolado, J. and Le Barbanchon, T. (2012), "Two-tier labour markets in the Great Recession: France versus Spain”, Economic Journal, 122 (562): F155-F187.

Bentolila, S., Jansen, M. and Jiménez, G. (2018), "When credit dries up: job losses in the Great Recession”, Journal of the European Economic Association, 16 (3): 650-695.

Berton, F., S. Mocetti, Presbitero, A. and Richiardi, M. (2018), "Banks, firms and jobs", Review of Financial Studies, forthcoming.

Bonnet, J., Cieply, S and Dejardin, M. (2005), "Financial constraints on new firms: looking for regional disparities", Brussels Economic Review, 48 (3): 217-245

Bonnet, J., Cieply, S and Dejardin, M. (2016), "Credit rationing or overlending? An exploration into financing imperfection", Applied Economics, 48 (57): 5563-558

Cahuc, P. and Zylberberg, A. (2014), Labor Economics, MIT Press, Cambridge.

Campello, M., Graham, J. and Harvey, C. (2010), "The real effects of financial constraints: evidence from a financial crisis", Journal of Financial Economics, 97(3): 470-487.

Chodorow-Reich, G. (2014), "The employment effects of credit market disruptions: firm-level evidence from the 2008-9 financial crisis", Quarterly Journal of Economics, 129(1): 1-59.

Cornille, D. (2015), "Results of the third wave of the survey on wage-setting in Belgium", Economic Review, National Bank of Belgium, December, 117-133.

Degryse, H., De Jonghe, O., Jakovljevic, S., Mullier, K. and Schepens, G. (2017), "The impact of bank shocks on firm-level outcomes and bank risk-taking”, mimeo. 
du Caju, P., Fuss, C. and Wintr, L. (2012), "Downward wage rigidity for different workers and firms", Brussels Economic Review, 55(1): 5-32.

Duygan-Bump, B., Levkov, A. and Montoriol-Garriga, J. (2015), "Financing constraints and unemployment: evidence from the Great Recession”, Journal of Monetary Economics, 75: 89-105.

Eurostat (2018), Labour Force Survey, Luxembourg.

Fabiani, S., Lamo, A., Messina, J. and Room, T. (2015), "European firm adjustment during times of economic crisis", IZA Journal of Labor Policy, 4: 24.

Fernandes, A. and Ferreira, P. (2017), "Financing constraints and fixed-term employment: evidence from the 2008-2009 financial crisis", European Economic Review, 72: 215-238.

Gerlach-Kirsten, P., O’Connell, B. and O'Toole, C. (2015), 'Do credit constraints affect SME investment and employment?", Economic and Social Review, 46(1): 51-86.

Hernando, I. and Martínez-Carrascal, C. (2008), "The impact of financial variables on firms' real decisions: evidence from Spanish firm-level data”, Journal of Macroeconomics, 30: 543-561.

Horrace, W. and Oaxaca, R. (2006), "Results on the bias and inconsistency of ordinary least squares for the linear probability model”, Economics Letters, 90: 321-327.

Hurley, J. (2010), "Belgium: short-time working and temporary layoff allowances", Eurofound, Dublin, 15p.

Izquierdo, M., Jimeno, J., Kosma, T., Lamo, A., Miljard, S., Room, T. and E. Viviano (2017), "Labour market adjustement in Europe during the crisis: microeconomic evidence from the Wage Dynamics Survey”, Bank of England Working Paper, No. 661, London.

Linehan, S., Reamonn, R. and J; Scally (2015). "Labour cost adjustment during the crisis: firm-level evidence", Quarterly Bulletin: 73-92.

Muller, P. Gagliardi, D., Valiandro, C., Bohn, N. and Klitou, D. (2014), Annual Report on SMEs 2013/2014 - A Partial and Fragile Recovery, European Commission, Brussels.

Nickell, S. and Nicolitsas, D. (1999), "How does financial pressure affect firms?”, European Economic Review, 43(8): 1435-1456.

ONSS (2018), Chômage temporaire et allocations annexes, National Employment Office, Brussels.

Piette, C. and Zachary, M.-D. (2015), "Sensitivity to the crisis of SME financing in Belgium", Economic Review, National Bank of Belgium, December, 31-45. 
Popov, A. and Rocholl, J. (2018), "Do credit shocks affect labor demand? Evidence from employment and wages during the financial crisis", Journal of Financial Intermediation, 36: $16-27$.

Poulsen, T. and Westergaard-Nielsen, N. (2017), "Credit constraints and job destruction: evidence from Denmark", Working Paper, Centre for Corporate Governance, Copenhagen Business School.

Siemer, M. (2014), "Firm entry and employment dynamics in the Great Recession", Finance and Economics Discussion Series, No. 2014-56, Board of Governors of the Federal Reserve System, U.S.

Spaliara, M. (2009), "Do financial factors affect the capital-labour ratio? Evidence from UK firm-level data", Journal of Banking and Finance, 33(10): 1932-1947.

Wooldridge, J. (2002), Econometric Analysis of Cross section and Panel Data, MIT Press, Cambridge (Ma.). 
Figure 1: Private-sector employment, Belgium in comparative perspective (Indices: 2008 Q3 = 100)

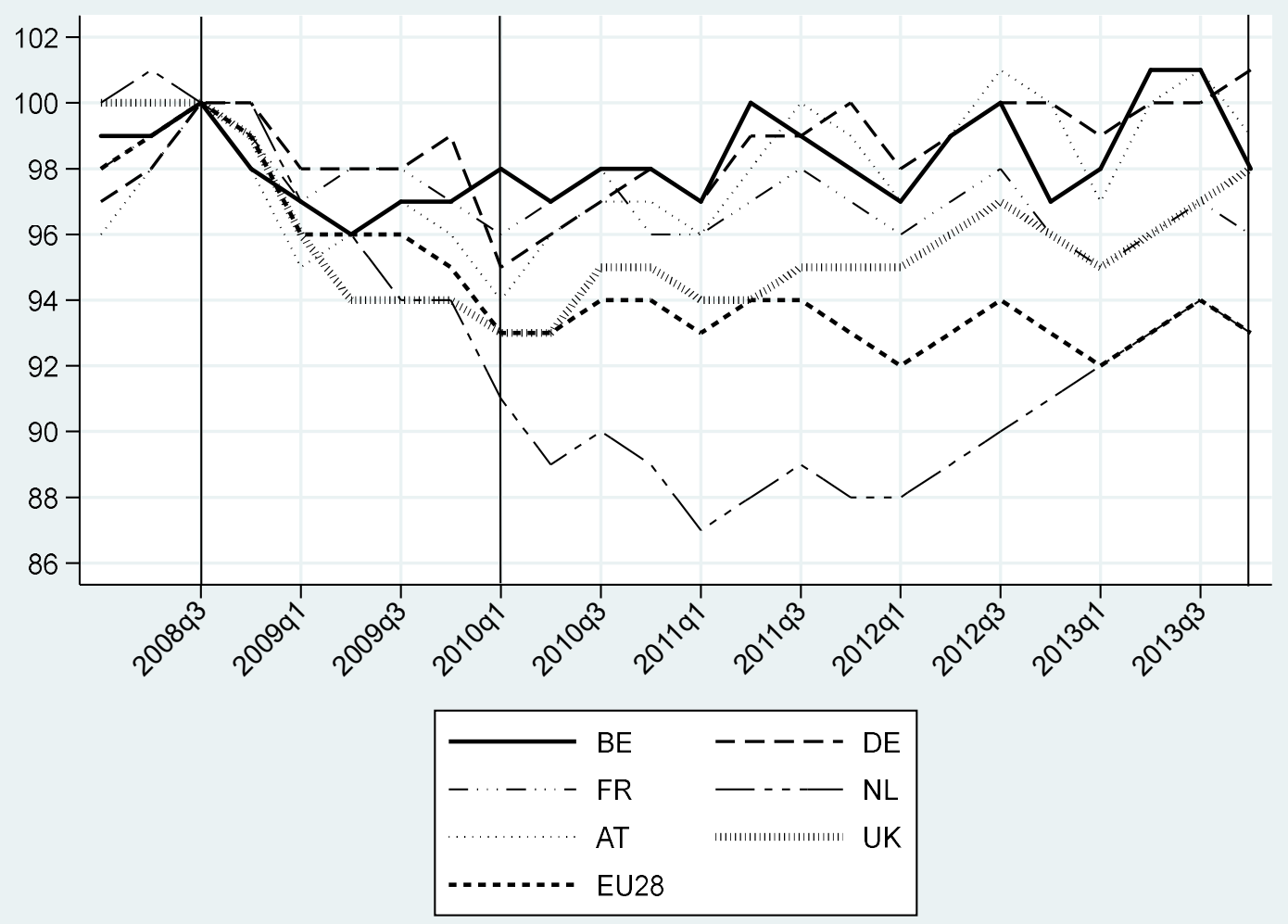

Note: The vertical lines identify respectively the beginning of the Great Recession (2008 Q3) and the period covered by our study (2010 Q1 - 2013 Q4), which corresponds to the European sovereign debt crisis. Source: Eurostat (2018). 
Figure 2: Private-sector employment in Belgium by sector of activity (Indices: 2008 Q3 = 100)

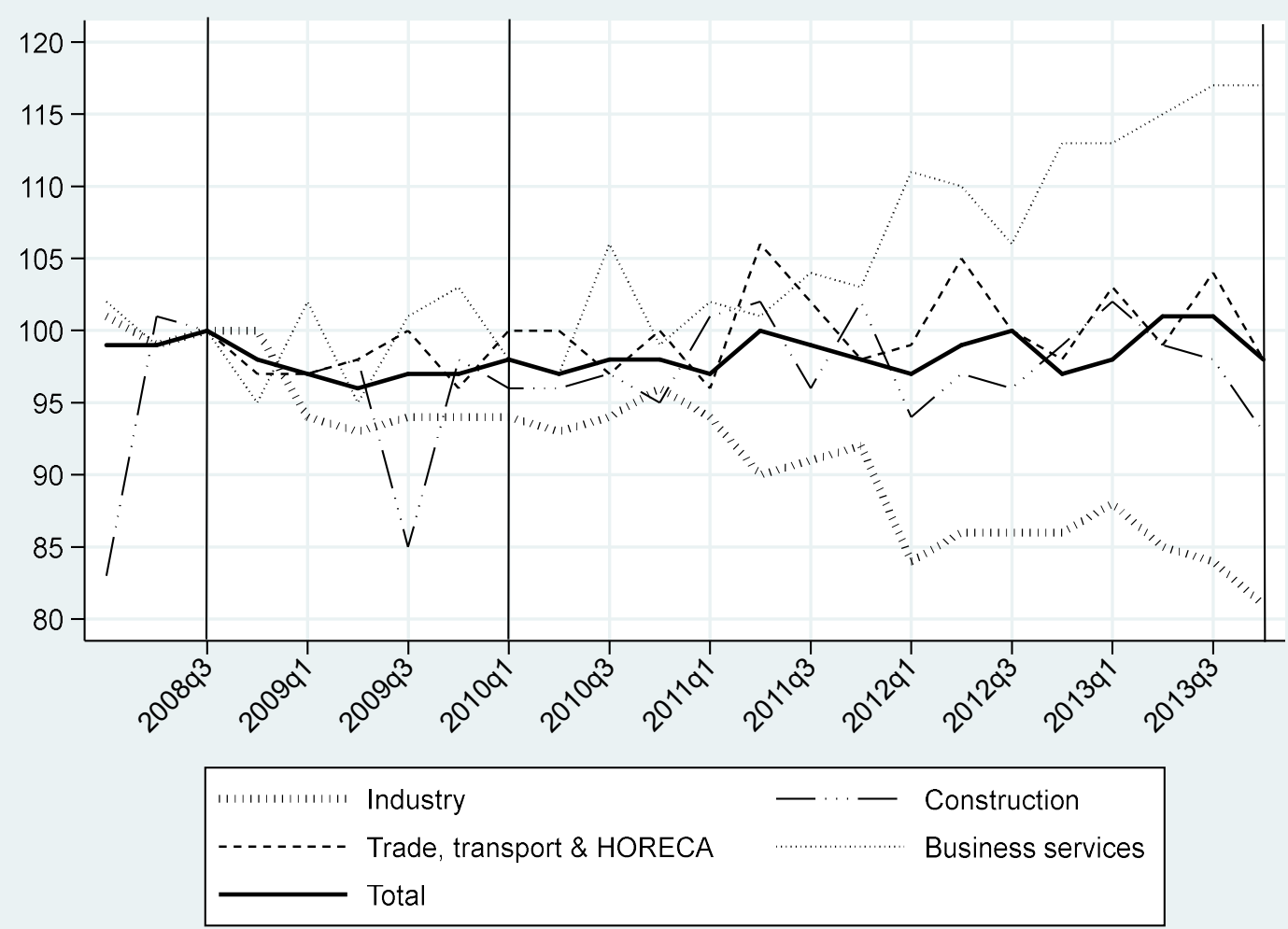

Note: The vertical lines identify respectively the beginning of the Great Recession (2008 Q3) and the period covered by our study (2010 Q1 - 2013 Q4), which corresponds to the European sovereign debt crisis. Source: Eurostat (2018). 
Table 1: Firm-level descriptive statistics, sample associated to LPM and probit regressions

\begin{tabular}{lcc}
\hline \hline Variables & Mean & Std. Dev. \\
\hline Type of adjustment measure: & & \\
Labour input reduction a & 0.33 & 0.47 \\
Extensive margin: & 0.31 & 0.46 \\
$\quad$ Collective layoffs & 0.01 & 0.12 \\
$\quad$ Individual layoffs & 0.28 & 0.45 \\
$\quad$ Temporary employment adjustment & 0.17 & 0.38 \\
$\quad$ Early retirement & 0.08 & 0.27 \\
Intensive margin: & 0.21 & 0.41 \\
$\quad$ Temporary layoffs (for economic reasons) & 0.17 & 0.38 \\
$\quad$ Reduction of working hours (subsidised or not) & 0.08 & 0.27 \\
Type of credit constraint: & & \\
Quantitative constraint: & 0.27 & 0.44 \\
$\quad$ To finance working capital & 0.16 & 0.37 \\
$\quad$ To finance new investment & 0.22 & 0.42 \\
$\quad$ To refinance debt & 0.16 & 0.37 \\
Cost constraint: & 0.23 & 0.42 \\
Firm characteristics: & & \\
Share of workers with tenure $\leq 5$ years & 0.37 & 0.25 \\
Share of high-skilled workers & 0.43 & 0.33 \\
Firm age (years) & 35.7 & 24.8 \\
Firm size (total number of employees) & 35.2 & 122.0 \\
Industry: & & \\
Manufacturing & 0.16 & \\
Construction & 0.14 & \\
Trade & 0.29 & \\
Business activities & 0.37 & \\
Financial intermediation & 0.03 & \\
Decrease in demand for firm's products/services & 0.52 & \\
Very strong competitive pressure for firm's main & & \\
product/service & 0.52 & \\
\hline Nor of & & \\
\hline
\end{tabular}

Number of observations ${ }^{\mathrm{b}}$ labour input or alter its composition between 2010 and 2013, and 0 otherwise. ${ }^{\mathrm{b}}$ Except for the 'Cost constraint' variable for which the number of observations is equal to 854 . Weighted descriptive statistics. 
Table 2: The impact of credit constraints on labour input reduction a, LPM estimates and marginal effects from probit regressions

\begin{tabular}{lcc}
\hline \hline & LPM & Probit \\
\hline & & \\
Quantitative credit constraint ${ }^{\mathrm{b}}$ & $\mathbf{0 . 0 9 9 * * *}$ & $\mathbf{0 . 1 0 0 * * *}$ \\
& $(0.034)$ & $(0.005)$ \\
Covariates: & 0.000 & $0.000^{* * *}$ \\
Firm age (in years) & $(0.001)$ & $(0.000)$ \\
& 0.000 & $0.000^{* * *}$ \\
Firm size (total number of employees) & $(0.000)$ & $(0.000)$ \\
& & \\
Industry: & Reference & Reference \\
Manufacturing & $-0.112^{* *}$ & $-0.115^{* * *}$ \\
Construction & $(0.055)$ & $(0.007)$ \\
& -0.064 & $-0.075^{* * *}$ \\
Trade & $(0.047)$ & $(0.006)$ \\
Business services & $-0.113^{* *}$ & $-0.119^{* * *}$ \\
& $(0.047)$ & $(0.006)$ \\
Financial intermediation & -0.010 & -0.013 \\
& $(0.095)$ & $(0.013)$ \\
Decrease of demand for firm's & $0.314^{* * *}$ & $0.320^{* * *}$ \\
products/services & $(0.031)$ & $(0.004)$ \\
Strong competitive pressure for firm's main & $0.099^{* *}$ & $0.134^{* * *}$ \\
product/service & $(0.040)$ & $(0.005)$ \\
Share of workers with tenure $\leq 5$ years & $0.002^{* *}$ & $0.002^{* * *}$ \\
Share of high-skilled workers & $(0.001)$ & $(0.000)$ \\
& -0.000 & $-0.000^{* * *}$ \\
R-squared & $(0.000)$ & $(0.000)$ \\
Pseudo R-squared & 0.16 & 0.13 \\
Number of observations & & 855 \\
\hline
\end{tabular}

Notes: ${ }^{a}$ The dependent variable is a dummy taking the value 1 if the firm needed to significantly reduce its labour input or alter its composition between 2010 and 2013, and 0 otherwise. ${ }^{\mathrm{b}}$ Dummy variable taking the value 1 if the firm faced a quantitative credit constraint between 2010 and 2013, i.e. declared that credit was not available. Weighted regressions. Robust standard errors reported between parentheses. $* * *, * *, *$ significant at 1 , 5 and 10 percent levels, respectively. 
Table 3: The impact of credit constraints on labour input reduction a, 2SLS estimates and marginal effects from bivariate probit regressions ${ }^{b}$

\begin{tabular}{|c|c|c|}
\hline & 2SLS & Bivariate probit \\
\hline Quantitative credit constraint $^{c}$ & $\begin{array}{c}\mathbf{0 . 5 0 9} * * * \\
(0.152)\end{array}$ & $\begin{array}{c}\mathbf{0 . 4 0 2 * * *} \\
(0.003)\end{array}$ \\
\hline Covariates $^{d}$ : & YES & YES \\
\hline Weak identification test statistic $^{\mathrm{e}}$ & $13.3 * * *$ & \\
\hline Overidentification test, $p$-value ${ }^{f}$ & 0.66 & \\
\hline Endogeneity test, $\mathrm{p}$-value ${ }^{\mathrm{g}}$ & 0.06 & \\
\hline Wald test $\chi^{2}, \mathrm{p}$-value ${ }^{\mathrm{h}}$ & & 0.00 \\
\hline R-squared & 0.37 & \\
\hline Number of observations & 522 & 522 \\
\hline
\end{tabular}

Notes: ${ }^{a}$ The dependent variable is a dummy taking the value 1 if the firm needed to significantly reduce its labour input or alter its composition between 2010 and 2013, and 0 otherwise. ${ }^{b}$ Instruments for the 2SLS and bivariate probit regressions include (in addition to covariates contained in the vector $X_{i}$ of equation (1)) the change in firms' main bank loan supply, the inverse value of this variable, and dummies for firms' main bank. ${ }^{\mathrm{c}}$ Dummy variable taking the value 1 if the firm faced a quantitative credit constraint between 2010 and 2013, i.e. declared that credit was not available. ${ }^{d}$ Covariates include the size and age of the firm, sectoral affiliation (4 dummies), change in demand for firm's products/services (1 dummy), competitive pressure for firm's main product/service (1 dummy), share of workers with at most 5 years of tenure, and share of high skilled workers. ${ }^{\mathrm{e}}$ Weak identification test reports Kleibergen-Paap rk Wald F statistic. ${ }^{\mathrm{f}}$ Overidentification test reports p-value of Hansen $\mathrm{J}$ statistic. ${ }^{\mathrm{g}}$ Endogeneity test shows probability that endogenous regressors can actually be treated as exogenous. ${ }^{\mathrm{h}}$ If the Wald test rejects the null hypothesis of no correlation between the error terms of the two probit regressions, the bivariate probit is recommended. Weighted regressions. Robust standard errors reported between parentheses. $* * *, * *, *$ significant at 1,5 and 10 percent levels, respectively. 
Table 4: The impact of cost credit constraints on labour input reduction a marginal effects from probit and bivariate probit regressions ${ }^{b}$

\begin{tabular}{|c|c|c|}
\hline & Probit & Bivariate probit $^{\mathrm{b}}$ \\
\hline Cost credit constraint to ${ }^{c}$ : & $\begin{array}{c}0.013 \\
(0.054)\end{array}$ & $\begin{array}{c}-0.154 \\
(0.265)\end{array}$ \\
\hline Covariates $^{d}$ : & YES & YES \\
\hline Pseudo R-squared & 0.15 & \\
\hline Wald test $\chi^{2}, p$-value ${ }^{\mathrm{e}}$ & & 0.38 \\
\hline Number of observations & 854 & 521 \\
\hline
\end{tabular}

Notes: ${ }^{\text {a }}$ The dependent variable is a dummy taking the value 1 if the firm needed to significantly reduce its labour input or alter its composition between 2010 and 2013, and 0 otherwise. ${ }^{b}$ Instruments for bivariate probit regressions include (in addition to covariates contained in the vector $X_{i}$ of equation (1)) the change in firms' main bank loan supply, the inverse value of this variable, and dummies for firms' main bank. ${ }^{c}$ Dummy variable taking the value 1 if the firm faced a cost credit constraint between 2010 and 2013 , i.e. declared that credit was available but that the conditions (interest rates and other contractual terms) were too onerous, and 0 otherwise. ${ }^{\mathrm{d}}$ Covariates include the size and age of the firm, sectoral affiliation (4 dummies), change in demand for firm's products/services ( 1 dummy), competitive pressure for firm's main product/service (1 dummy), share of workers with at most 5 years of tenure, and share of high skilled workers. Weighted regressions. Robust standard errors reported between parentheses. ${ }^{\mathrm{e}}$ If the

Wald test rejects the null hypothesis of no correlation between the error terms of the two probit regressions, the bivariate probit is recommended. $* * * * * *$ significant at 1,5 and 10 percent levels, respectively. 
Table 5: The impact of quantitative credit constraints on labour input reduction, according to the type of loan application made ${ }^{a}$, marginal effects from bivariate probit regressions ${ }^{b}$

Bivariate probit ${ }^{\mathrm{b}}$

\begin{tabular}{|c|c|c|c|}
\hline \multicolumn{4}{|c|}{ Quantitative credit constraint to ${ }^{c}$ : } \\
\hline Finance working capital & $\begin{array}{c}\mathbf{0 . 4 5 2} * * * \\
(0.004)\end{array}$ & & \\
\hline Finance new investment & \multicolumn{3}{|c|}{$\begin{array}{c}\mathbf{0 . 4 0 7} * * * \\
(0.004)\end{array}$} \\
\hline Refinance debt & & & $\begin{array}{c}\mathbf{0 . 4 9 4} * * * \\
(0.004)\end{array}$ \\
\hline Covariates $^{d}$ : & YES & YES & YES \\
\hline Wald test $\chi^{2}, p$-value ${ }^{\mathrm{e}}$ & 0.00 & 0.00 & 0.00 \\
\hline Number of observations & 521 & 521 & 524 \\
\hline
\end{tabular}

Notes: ${ }^{\text {a }}$ The dependent variable is a dummy taking the value 1 if the firm needed to significantly reduce its labour input or alter its composition between 2010 and 2013, and 0 otherwise. ${ }^{b}$ Instruments for bivariate probit regressions include (in addition to covariates contained in the vector $X_{i}$ of equation (1)) the change in firms' main bank loan supply, the inverse value of this variable, and dummies for firms' main bank. ${ }^{\mathrm{c}}$ Dummy variable taking the value 1 if the firm faced a quantitative credit constraint between 2010 and 2013, i.e. declared that credit was not available. ${ }^{\mathrm{d}}$ Covariates include the size and age of the firm, sectoral affiliation (4 dummies), change in demand for firm's products/services (1 dummy), competitive pressure for firm's main product/service (1 dummy), share of workers with at most 5 years of tenure, and share of high skilled workers. Weighted regressions. Robust standard errors reported between parentheses. ${ }^{\mathrm{e}}$ If the Wald test rejects the null hypothesis of no correlation between the error terms of the two probit regressions, the bivariate probit is recommended. ***,**,* significant at 1,5 and 10 percent levels, respectively. 
Table 6: The impact of credit constraints on labour input reduction ${ }^{\text {a }}$, according to changes in demand for firms' products and/or services, marginal effects from probit and bivariate probit $^{\mathbf{b}}$ regressions $^{2}$

\begin{tabular}{|c|c|c|c|c|}
\hline & \multicolumn{2}{|c|}{$\begin{array}{c}\Delta \text { demand } \\
<0^{c}\end{array}$} & \multicolumn{2}{|c|}{$\begin{array}{c}\Delta \text { demand } \\
\geq 0^{\mathrm{d}}\end{array}$} \\
\hline & Probit & Bivariate probit & Probit & Bivariate probit \\
\hline Quantitative credit constraint $^{\mathrm{e}}$ & $\begin{array}{c}\mathbf{0 . 2 2 2} * * * \\
(0.007)\end{array}$ & $\begin{array}{c}\mathbf{0 . 4 6 1 * * *} \\
(0.005)\end{array}$ & $\begin{array}{l}-0.050 \\
(0.058)\end{array}$ & $\begin{array}{l}-0.170 \\
(0.266)\end{array}$ \\
\hline Covariates $^{f}$ : & YES & YES & YES & YES \\
\hline Pseudo R-squared & 0.08 & & 0.07 & \\
\hline Wald test $\chi^{2}$, p-value $^{\mathrm{g}}$ & & 0.00 & & 0.66 \\
\hline Number of observations & 434 & 278 & 421 & 263 \\
\hline
\end{tabular}

\footnotetext{
Notes: ${ }^{a}$ The dependent variable is a dummy taking the value 1 if the firm needed to significantly reduce its labour input or alter its composition between 2010 and 2013, and 0 otherwise. ${ }^{\mathrm{b}}$ Instruments for bivariate probit regressions include (in addition to covariates contained in the vector $X_{i}$ of equation (1)) the change in firms' main bank loan supply, the inverse value of this variable (except for $\Delta$ demand $<0$ ), and dummies for firms' main bank (except for $\Delta$ demand $<0$ ). ${ }^{\mathrm{c}}$ Sample of firms that have experienced a decreasing demand for their products and/or services between 2010 and 2013. ${ }^{\mathrm{d}}$ Sample of firms that have experienced an unchanged or increasing demand for their products and/or services between 2010 and 2013. ${ }^{\text {e }}$ Dummy variable taking the value 1 if the firm faced a quantitative credit constraint between 2010 and 2013, i.e. declared that credit was not available. ${ }^{f}$ Covariates include the size and age of the firm, sectoral affiliation (4 dummies), competitive pressure for firm's main product/service (1 dummy), share of workers with at most 5 years of tenure, and share of high skilled workers. ${ }^{\mathrm{g}}$ If the Wald test rejects the null hypothesis of no correlation between the error terms of the two probit regressions, the bivariate probit is recommended. Weighted regressions. Robust standard errors reported between parentheses. $* * *, * * *$ significant at 1,5 and 10 percent levels, respectively.
} 
Table 7: The impact of credit constraints on labour input reduction ${ }^{\text {a }}$, according to the degree of competition on firm's main product/service market, marginal effects from probit and bivariate probit ${ }^{\mathrm{b}}$ regressions

$$
\text { Stronger competition }^{c} \quad \text { Weaker competition }^{\mathrm{d}}
$$

\begin{tabular}{|c|c|c|c|c|}
\hline & Probit & Bivariate probit & Probit & Bivariate probit \\
\hline Quantitative credit constraint ${ }^{\mathrm{e}}$ & $\begin{array}{c}\mathbf{0 . 0 9 0 * * *} \\
(0.007)\end{array}$ & $\begin{array}{c}\mathbf{0 . 3 6 4 * * *} \\
(0.024)\end{array}$ & $\begin{array}{c}0.115 \\
(0.008)\end{array}$ & $\begin{array}{c}-0.184 \\
(0.831)\end{array}$ \\
\hline Covariates $^{f}$ : & YES & YES & YES & YES \\
\hline Pseudo R-squared & 0.07 & & 0.24 & \\
\hline Wald test $\chi^{2}, p$-value ${ }^{g}$ & & 0.00 & & 0.00 \\
\hline Number of observations & 449 & 266 & 406 & 275 \\
\hline
\end{tabular}

\begin{abstract}
Notes: a The dependent variable is a dummy taking the value 1 if the firm needed to significantly reduce its labour input or alter its composition between 2010 and 2013, and 0 otherwise. ${ }^{\mathrm{b}}$ Instruments for bivariate probit regressions include (in addition to covariates contained in the vector $X_{i}$ of equation (1)) the change in firms' main bank loan supply, the inverse value of this variable, and dummies for firms' main bank. ${ }^{c}$ Sample of firms experiencing very severe competition on their main product/service market. ${ }^{d}$ Sample of firms experiencing severe, moderate or weak competition on their main product/service market. ${ }^{\mathrm{e}}$ Dummy variable taking the value 1 if the firm faced a quantitative credit constraint between 2010 and 2013, i.e. declared that credit was not available ${ }^{\mathrm{f}}$ Covariates include the size and age of the firm, sectoral affiliation (4 dummies), competitive pressure for firm's main product/service ( 1 dummy), share of workers with at most 5 years of tenure, and share of high skilled workers. ${ }^{\mathrm{g}}$ If the Wald test rejects the null hypothesis of no correlation between the error terms of the two probit regressions, the bivariate probit is recommended. Weighted regressions. Robust standard errors reported between parentheses. $* * *, * *, *$ significant at 1,5 and 10 percent levels, respectively
\end{abstract}


Table 8: The impact of credit constraints on the extensive $e^{a}$ and intensive $e^{b}$ margins, marginal effects from probit and bivariate probit ${ }^{\mathrm{c}}$ regressions

\begin{tabular}{|c|c|c|c|c|}
\hline & \multicolumn{2}{|c|}{ Extensive margin ${ }^{\mathrm{a}}$} & \multicolumn{2}{|c|}{ Intensive margin ${ }^{\mathrm{b}}$} \\
\hline & Probit & Bivariate probit & Probit & Bivariate probit \\
\hline Quantitative credit constraint $^{\mathrm{d}}$ & $\begin{array}{c}\mathbf{0 . 0 9 0} * * * \\
(0.005)\end{array}$ & $\begin{array}{c}\mathbf{0 . 4 0 3} * * * \\
(0.003)\end{array}$ & $\begin{array}{c}\mathbf{0 . 0 5 2} * * * \\
(0.004)\end{array}$ & $\begin{array}{c}\mathbf{0 . 2 9 2} * * * \\
(0.015)\end{array}$ \\
\hline Covariates $^{e}$ : & YES & YES & YES & YES \\
\hline Pseudo R-squared & 0.12 & & 0.13 & \\
\hline Wald test $\chi^{2}, p$-value ${ }^{\mathrm{f}}$ & & 0.00 & & 0.00 \\
\hline Number of observations & 855 & 522 & 842 & 522 \\
\hline
\end{tabular}

\footnotetext{
Notes: ${ }^{a}$ The dependent variable is a dummy taking the value 1 if the firm relied (marginally, moderately or strongly) on collective layoffs, individual layoffs, non-renewal of temporary contracts at expiration, early retirement schemes and/or reduction of agency workers between 2010 and 2013, and 0 otherwise. ${ }^{b}$ The dependent variable is a dummy taking the value 1 if the firm relied (marginally, moderately or strongly) on temporary layoffs (for economic reasons), subsidised reduction of working hours and/or non-subsidised reduction of working hours (including reduction of overtime) between 2010 and 2013, and 0 otherwise. ${ }^{\mathrm{c}}$ Instruments for bivariate probit regressions include (in addition to covariates contained in the vector $X_{i}$ of equation (1)) the change in firms' main bank loan supply, the inverse value of this variable, and dummies for firms' main bank. ${ }^{\mathrm{d}}$ Dummy variable taking the value 1 if the firm faced a quantitative credit constraint between 2010 and 2013, i.e. declared that credit was not available. ${ }^{\mathrm{e}}$ Covariates include the size and age of the firm, sectoral affiliation (4 dummies), competitive pressure for firm's main product/service (1 dummy), share of workers with at most 5 years of tenure, and share of high skilled workers. ${ }^{\mathrm{f}}$ If the Wald test rejects the null hypothesis of no correlation between the error terms of the two probit regressions, the bivariate probit is recommended. Weighted regressions. Robust standard errors reported between parentheses. $* * *, * *, *$ significant at 1,5 and 10 percent levels, respectively
} 
Table 9: The impact of credit constraints on different components of the extensive margin a , marginal effects from probit and bivariate probit ${ }^{\mathrm{c}}$ regressions

\begin{tabular}{|c|c|c|c|c|c|c|c|c|}
\hline & \multicolumn{2}{|c|}{ Collective layoffs $^{\mathrm{a}}$} & \multicolumn{2}{|c|}{ Individual layoffs $^{\mathrm{a}}$} & \multicolumn{2}{|c|}{$\begin{array}{c}\text { Adjustment temporary } \\
\text { employment }^{\text {a }}\end{array}$} & \multicolumn{2}{|c|}{ Early retirement $^{\mathrm{a}}$} \\
\hline & Probit & $\begin{array}{l}\text { Bivariate } \\
\text { probit }\end{array}$ & Probit & $\begin{array}{l}\text { Bivariate } \\
\text { probit }\end{array}$ & Probit & $\begin{array}{c}\text { Bivariate } \\
\text { probit }\end{array}$ & Probit & $\begin{array}{c}\text { Bivariate } \\
\text { probit }\end{array}$ \\
\hline $\begin{array}{l}\text { Quantitative credit } \\
\text { constraint }^{\mathrm{d}}\end{array}$ & $\begin{array}{l}-0.003 \\
(0.003)\end{array}$ & $\begin{array}{l}-0.024 \\
(0.045)\end{array}$ & $\begin{array}{c}\mathbf{0 . 1 1 5 * * *} \\
(0.005)\end{array}$ & $\begin{array}{c}\mathbf{0 . 4 0 1 * * *} \\
(0.003)\end{array}$ & $\begin{array}{c}\mathbf{0 . 0 1 0} * * * \\
(0.003)\end{array}$ & $\begin{array}{c}\mathbf{0 . 2 8 2} * * * \\
(0.009)\end{array}$ & $\begin{array}{c}\mathbf{0 . 0 4 4 * * *} \\
(0.002)\end{array}$ & $\begin{array}{l}\mathbf{0 . 3 0 0 * * *} \\
(0.008)\end{array}$ \\
\hline Covariates $^{e}$ : & YES & YES & YES & YES & YES & YES & YES & YES \\
\hline Pseudo R-squared & 0.19 & & 0.12 & & 0.17 & & 0.20 & \\
\hline $\begin{array}{l}\text { Wald test } \chi^{2} \text {, } \\
\text { p-value }\end{array}$ & & 0.80 & & 0.00 & & 0.00 & & 0.00 \\
\hline $\begin{array}{l}\text { Number of } \\
\text { observations }\end{array}$ & 842 & 522 & 855 & 522 & 855 & 522 & 855 & 542 \\
\hline \multicolumn{9}{|c|}{$\begin{array}{l}\text { Notes: a The dependent variable is a dummy taking the value } 1 \text { if the firm relied (marginally, moderately or strongly) respectively on: i) collective layoffs, ii) individual layoffs, iii) non-renewal } \\
\text { of temporary contracts at expiration and/or reduction of agency workers, and iv) early retirement schemes between } 2010 \text { and } 2013 \text {, and } 0 \text { otherwise. }{ }^{c} \text { Instruments for bivariate probit } \\
\text { regressions include (in addition to covariates contained in the vector } X i \text { of equation }(1) \text { ) the change in firms' main bank loan supply, the inverse value of this variable (except } \\
\text { for early retirement), and dummies for firms' main bank. }{ }^{\mathrm{d}} \text { Dummy variable taking the value } 1 \text { if the firm faced a quantitative credit constraint between } 2010 \text { and } 2013 \text {, i.e. } \\
\text { declared that credit was not available. }{ }^{\text {e }} \text { Covariates include the size and age of the firm, sectoral affiliation ( } 4 \text { dummies), competitive pressure for firm's main product/service } \\
\left(1 \text { dummy), share of workers with at most } 5 \text { years of tenure, and share of high skilled workers. }{ }^{f} \text { If the Wald test rejects the null hypothesis of no correlation between the error }\right. \\
\text { terms of the two probit regressions, the bivariate probit is recommended. Weighted regressions (weights taken from WDN survey, i.e. variable wb). Robust standard errors } \\
\text { reported between parentheses. } * * * * * * \text { significant at } 1,5 \text { and } 10 \text { percent levels, respectively. }\end{array}$} \\
\hline
\end{tabular}


Table 10: The impact of credit constraints on different components of the intensive margin a, marginal effects from probit and bivariate probit $^{\mathrm{c}}$ regressions $^{2}$

\begin{tabular}{|c|c|c|c|c|}
\hline & \multicolumn{2}{|c|}{$\begin{array}{c}\text { Temporary layoffs } \\
\text { (for economic reasons) }^{\mathrm{a}}\end{array}$} & \multicolumn{2}{|c|}{$\begin{array}{c}\text { Reduction of working } \\
\text { hours }^{\mathrm{a}}\end{array}$} \\
\hline & Probit & Bivariate probit & Probit & Bivariate probit \\
\hline Quantitative credit constraint $^{\mathrm{d}}$ & $\begin{array}{l}\mathbf{0 . 0 7 5 * * *} \\
(0.004)\end{array}$ & $\begin{array}{c}\mathbf{0 . 3 5 2 * * *} \\
(0.066)\end{array}$ & $\begin{array}{l}-0.034 \\
(0.022)\end{array}$ & $\begin{array}{c}0.025 \\
(0.141)\end{array}$ \\
\hline Covariates $^{e}$ : & YES & YES & YES & YES \\
\hline Pseudo R-squared & 0.17 & & 0.12 & \\
\hline $\begin{array}{l}\text { Wald test } \chi^{2} \\
\text { p-value }^{f}\end{array}$ & & 0.01 & & 0.71 \\
\hline Number of observations & 842 & 551 & 842 & 522 \\
\hline
\end{tabular}

Notes: ${ }^{\text {a }}$ The dependent variable is a dummy taking the value 1 if the firm relied (marginally, moderately or strongly) respectively on: i) temporary layoffs (for economic reasons), ii) subsidised reduction of working hours and/or non-subsidised reduction of working hours (including reduction of overtime) between 2010 and 2013, and 0 otherwise. ${ }^{c}$ Instruments for bivariate probit regressions include (in addition to covariates contained in the vector $X_{i}$ of equation (1)) the change in firms' main bank loan supply, the inverse value of this variable (except for temporary layoffs), and dummies for firms' main bank (except for temporary layoffs). ${ }^{\mathrm{d}}$ Dummy variable taking the value 1 if the firm faced a quantitative credit constraint between 2010 and 2013, i.e. declared that credit was not available. ${ }^{\mathrm{e}}$ Covariates include the size and age of the firm, sectoral affiliation (4 dummies), competitive pressure for firm's main product/service ( 1 dummy), share of workers with at most 5 years of tenure, and share of high skilled workers. ${ }^{\mathrm{f}}$ If the Wald test rejects the null hypothesis of no correlation between the error terms of the two probit regressions, the bivariate probit is recommended. Weighted regressions (weights taken from WDN survey, i.e. variable wb). Robust standard errors reported between parentheses. ***, **,* significant at 1,5 and 10 percent levels, respectively. 
Appendix 1: Firm-level descriptive statistics, sample associated to 2SLS and bivariate probit regressions

\begin{tabular}{|c|c|c|}
\hline Variables & Mean & Std. Dev. \\
\hline \multicolumn{3}{|l|}{ Type of adjustment measure: } \\
\hline Labour input reduction $^{\text {a }}$ & 0.29 & 0.46 \\
\hline Extensive margin: & 0.27 & 0.45 \\
\hline Collective layoffs & 0.02 & 0.13 \\
\hline Individual layoffs & 0.25 & 0.43 \\
\hline Temporary employment adjustment & 0.17 & 0.37 \\
\hline Early retirement & 0.03 & 0.18 \\
\hline Intensive margin: & 0.20 & 0.40 \\
\hline Temporary layoffs (for economic reasons) & 0.18 & 0.38 \\
\hline Reduction of working hours (subsidised or not) & 0.08 & 0.27 \\
\hline \multicolumn{3}{|l|}{ Type credit constraint: } \\
\hline Quantitative constraint: & 0.33 & 0.47 \\
\hline To finance working capital & 0.23 & 0.42 \\
\hline To finance new investment & 0.29 & 0.45 \\
\hline To refinance debt & 0.18 & 0.39 \\
\hline Cost constraint: & 0.31 & 0.46 \\
\hline \multicolumn{3}{|l|}{ Firm characteristics: } \\
\hline Share of workers with tenure $\leq 5$ years & 0.37 & 0.25 \\
\hline Share of high-skilled workers & 0.44 & 0.32 \\
\hline Firm age (years) & 36.4 & 22.7 \\
\hline Firm size (total number of employees) & 30.4 & 135.1 \\
\hline \multicolumn{3}{|l|}{ Industry: } \\
\hline Manufacturing & 0.20 & 0.40 \\
\hline Construction & 0.18 & 0.38 \\
\hline Trade & 0.27 & 0.44 \\
\hline Business activities & 0.36 & 0.48 \\
\hline Financial intermediation & 0.00 & 0.00 \\
\hline Decrease in demand for firm's products/services & 0.51 & 0.50 \\
\hline $\begin{array}{l}\text { Very strong competitive pressure for firm's main } \\
\text { product/service }\end{array}$ & 0.48 & 0.50 \\
\hline
\end{tabular}

Number of observations $^{\mathrm{b}} \quad 522$

Notes: ${ }^{a}$ Dummy taking the value 1 if the firm needed to significantly reduce its labour input or alter its composition between 2010 and 2013, and 0 otherwise. ${ }^{\text {b }}$ Except for the 'Cost constraint' variable for which the number of observations is equal to 526 . Weighted descriptive statistics. 
Appendix 2: Firm-level descriptive statistics of instruments, sample associated to 2SLS and bivariate probit regressions

\begin{tabular}{lcc}
\hline \hline Variables & Mean & St. Dev. \\
\hline $\begin{array}{l}\text { \% change in firm's main bank loan supply before and } \\
\text { after the crisis (MBLS) }{ }^{a}\end{array}$ & 2.07 & 0.54 \\
Inverse of MBLS & 0.50 & \\
Firm's main bank dummies & & \\
Bank 1 & 0.000 & \\
Bank 2 & 0.011 & \\
Bank 3 & 0.001 & \\
Bank 4 & 0.022 & \\
Bank 5 & 0.030 & \\
Bank 6 & 0.002 & \\
Bank 7 & 0.007 & \\
Bank 8 & 0.434 & \\
Bank 9 & 0.017 & \\
Bank 10 & 0.002 & \\
Bank 11 & 0.012 & \\
Bank 12 & 0.002 & \\
Bank 13 & 0.000 & \\
Bank 14 & 0.009 & \\
Bank 15 & 0.237 & \\
Bank 16 & 0.213 & \\
\hline Number of observations & & \\
\hline
\end{tabular}

Notes: a The exact definition of this variable is as follows: \% change in the number of loans made by the firm's $i$ main bank to all borrowers other than firm $i$ before (i.e. October 2005 - June 2007) and after (i.e. October 2008 - June 2011) the crisis, normalized by the number of loans made by the firm's $i$ main bank before the crisis. Weighted descriptive statistics. 
Appendix 3: Determinants of quantitative credit constraints, i.e. first-stage of 2 SLS and bivariate probit regressions for labour input reduction

First-stage estimates of:

2SLS

Bivariate probit

\begin{tabular}{|c|c|c|}
\hline & (1) & (2) \\
\hline \multicolumn{3}{|l|}{ Instrumental variables: } \\
\hline $\begin{array}{l}\% \text { change in firm's main bank loan supply } \\
\text { before and after the crisis (MBLS) }\end{array}$ & $\begin{array}{l}-\mathbf{- 0 . 2 7 6 * *} \\
(0.131)\end{array}$ & $\begin{array}{l}-\mathbf{- 0 . 8 0 2} * * * \\
(0.039)\end{array}$ \\
\hline Inverse of MBLS & $\begin{array}{l}-0.065 \\
(0.070)\end{array}$ & $\begin{array}{c}-\mathbf{0 . 1 8 0} * * * \\
(0.028)\end{array}$ \\
\hline \multicolumn{3}{|l|}{ Firm's main bank dummies: } \\
\hline Bank 1 & $\begin{array}{l}-\mathbf{0 . 9 2 3} * * * \\
(0.188)\end{array}$ & $\begin{array}{c}-8.032 \\
(26,594.15)\end{array}$ \\
\hline Bank 2 & $\begin{array}{c}-\mathbf{0 . 5 2 6 * * *} \\
(0.147)\end{array}$ & $\begin{array}{c}-6.840 \\
(28,16.24)\end{array}$ \\
\hline Bank 3 & $\begin{array}{l}-\mathbf{- 0 . 4 3 0 * * *} \\
(0.081)\end{array}$ & $\begin{array}{c}-6.673 \\
(13,120.89)\end{array}$ \\
\hline Bank 4 & $\begin{array}{l}-\mathbf{0 . 3 2 8 * * *} \\
(0.076)\end{array}$ & $\begin{array}{c}-5.945 \\
(1,013.92)\end{array}$ \\
\hline Bank 5 & $\begin{array}{c}0.051 \\
(0.290)\end{array}$ & $\begin{array}{c}\mathbf{0 . 3 8 8} * * * \\
(0.041)\end{array}$ \\
\hline Bank 6 & $\begin{array}{l}-\mathbf{- 0 . 4 3 5 * * *} \\
(0.101)\end{array}$ & $\begin{array}{c}-6.645 \\
(7,400.11)\end{array}$ \\
\hline Bank 7 & $\begin{array}{l}-\mathbf{- 0 . 3 5 0 * * *} \\
(0.120)\end{array}$ & $\begin{array}{l}-1.075 * * * \\
(0.099)\end{array}$ \\
\hline Bank 8 & Reference & Reference \\
\hline Bank 9 & $\begin{array}{c}0.474 \\
(0.360)\end{array}$ & $\begin{array}{l}1.160 * * * \\
(0.054)\end{array}$ \\
\hline Bank 10 & $\begin{array}{l}-\mathbf{0 . 3 6 8 *} \\
(0.202)\end{array}$ & $\begin{array}{l}-0.045 \\
(0.171)\end{array}$ \\
\hline Bank 11 & $\begin{array}{l}-0.315 \\
(0.199)\end{array}$ & $\begin{array}{l}-\mathbf{0 . 9 6 8 * * *} \\
(0.071)\end{array}$ \\
\hline Bank 12 & $\begin{array}{c}\mathbf{0 . 6 5 0} * * * \\
(0.120)\end{array}$ & $\begin{array}{c}7.647 \\
(8,889.05)\end{array}$ \\
\hline Bank 13 & $\begin{array}{l}-\mathbf{- 0 . 4 5 8 * * *} \\
(0.105)\end{array}$ & $\begin{array}{c}-6.898 \\
(41,146.4)\end{array}$ \\
\hline Bank 14 & $\begin{array}{l}-0.099 \\
(0.237)\end{array}$ & $\begin{array}{l}-\mathbf{0 . 4 9 1 * * *} \\
(0.073)\end{array}$ \\
\hline Bank 15 & $\begin{array}{l}-0.059 \\
(0.084)\end{array}$ & $\begin{array}{l}-0.005 \\
(0.017)\end{array}$ \\
\hline Bank 16 & $\begin{array}{c}-0.019 \\
(0.101)\end{array}$ & $\begin{array}{c}\mathbf{0 . 0 3 8}^{* *} \\
(0.017)\end{array}$ \\
\hline Other covariates ${ }^{c}$ : & YES & YES \\
\hline \multirow{2}{*}{$\begin{array}{l}\text { Sanderson-Windmeijer (SW) multivariate F-test of } \\
\text { excluded instruments }{ }^{\mathrm{d}} \\
\text { Number of observations }\end{array}$} & $13.33 * * *$ & \\
\hline & 522 & 522 \\
\hline \multicolumn{3}{|c|}{$\begin{array}{l}\text { Notes: }^{\text {a }} \text { The dependent variable is a dummy variable taking the value } 1 \text { if the firm faced a quantitative credit constraint between } \\
2010 \text { and } 2013 \text {, i.e. declared that credit was not available. }{ }^{b} \text { The exact definition of this variable is as follows: \% change in the } \\
\text { number of loans made by the firm's } i \text { main bank to all borrowers other than firm } i \text { before (i.e. October } 2005-\text { June } 2007) \text { and } \\
\text { after (i.e. October } 2008 \text { - June } 2011 \text { ) the crisis, normalized by the number of loans made by the firm's } i \text { main bank before the } \\
\text { crisis. ' Regressions also control for firm age and size, sectoral affiliation ( } 4 \text { dummies), change in demand for firm's } \\
\text { products/services ( } 1 \text { dummy), competitive pressure for firm's main product/service ( } 1 \text { dummy), share of workers with at most } 5 \\
\text { years of tenure, and share of high skilled workers. }{ }^{d} \text { Given that there is a single endogeneous regressor (i.e. the credit } \\
\text { constraint), the SW statistic is identical to the Kleibergen-Paap rk Wald statistic for weak identification (as the robust option has } \\
\text { been requested in Stata). Robust standard errors reported between parentheses. } * * * * * * \text { significant at } 1,5 \text { and } 10 \text { percent } \\
\text { levels, respectively. }\end{array}$} \\
\hline
\end{tabular}

